\title{
Regulation of Seed Germination and the Role of Aquaporins under Abiotic Stress
}

\author{
Erina Kshetrimayum, Debee Prasad Sahoo, Jayeeta Mitra, Sanjib Kumar Panda*
}

Department of Life Science \& Bioinformatics, Assam University, Silchar, India

\begin{abstract}
Aquaporins play a major role in governing the movement of water between neighboring cells during seed germination and are major players in response to abiotic stress conditions that affect water availability. Seeds of pea (Pisum sativum L. cv. Arkel) were used for studying cell growth, expression and function of aquaporins during seed imbibition, radicle emergence and growth.Water channel functioning checked by inhibitory test with mercuric chloride showed closed water channels prior to growth initiation. Addition of mercury scavenging agents dithiothreitol and $\beta$-mercaptoethanol along with the $\mathrm{HgCl}_{2}$ overcame the observed inhibitory effects in terms of moisture content. The presence of aquaporin inhibitors $\left(\mathrm{HgCl}_{2}\right.$ and $\left.\mathrm{ZnCl}_{2}\right)$ and $\mathrm{NaCl}$ reduced seedling growth. Here we studied expression of a plasma membrane intrinsic protein $(P s P I P 1 ; 2)$ and a tonoplast intrinsic protein $(P s T I P 1 ; 1)$ by using the semi quantitative RT-PCR in the germinated seedlings exposed to different abiotic stresses. Treatment with $\mathrm{NaCl}, \mathrm{HgCl}$ and $\mathrm{ZnCl}_{2}$ differentially regulated gene expression in radicle, cotyledon and plumule. $\mathrm{NaCl}$ and $\mathrm{Hg}$, upregulated expression of PSPIP1;2 and $P S T I P 1 ; 1$ in radicle and expression of PsTIP1;1 was significantly upregulated in radicle and suppressed in cotyledon by $\mathrm{Zn}$. A possible role for aquaporins in germinating seeds and seedling response to abiotic stresses is discussed.
\end{abstract}

Keywords-Seed germination, Aquaporins, Pisum sativum L., Heavy metals, dithiothreitol (DTT), ß-mercaptoethanol $(\mathrm{ME})$.

\section{INTRODUCTION}

Seed germination determines successful crop production and is usually the most critical stage in seedling establishment (Almansouri et al. 2001; Bhattacharjee 2008). The germination of seeds requires great adeptness since the process is very complex, a seed from its stillness is woken up to its active state (Dow \& Schwintzer 1999). Imbibition of water marks the onset of germination of seeds and triggers arrested metabolic activities which culminates in the emission of a radicle and finalization of germination (Nanogaki et al. 2010). Water moves through the plant tissue via three different pathways: the apoplastic pathway through cell walls and intercellular spaces, the symplastic path from cell to cell either through cytoplasm and plasmodesmata, the transcellular path traversing through cell membranes. The movement of water via the transcellular path involves aquaporins, which are water selective channels (Preston et al. 1992; Agre et al. 1998).

Plant aquaporins fall into five subfamilies: the plasma membrane intrinsic proteins (PIPs), the tonoplast intrinsic proteins (TIPs), the nodulin26-like intrinsic proteins (NIPs), the small basic intrinsic proteins (SIPs), and the uncategorized $\mathrm{X}$ intrinsic proteins (XIPs) (Maurel et al. 2015). Aquaporins are concentrated in zones of cell division and enlargement, play a major role in governing the movement of water between neighboring cells during seed germination (Tyerman et al. 2002; Jain et al. 2008). Recent studies have implicated the importance of aquaporins in seed imbibition and subsequent germination (Schuurmans et al. 2003; Liu et al. 2007; Liu et al. 2013; Cardoso et al. 2015). The function of seed aquaporins may be related to the water imbibition and activation of the metabolic system in the seed, which results in higher germination (Liu et al. 2007).

Seed germination occurs only when conditions become favorable. Seeds in their germinating stage are highly sensitive and germination is arrested by various heavy metals like mercury, cadmium and zinc etc. (Du et al. 2004; Chugh \& Sawhney 1996; Rout \& Das 2009). Mercury is widely believed to block aquaporins by binding to a cysteine residue located in close proximity to the aqueous pore of the protein (Daniels et al. 1994; Agre et al. 1998). Due to its aquaporins blocking activity (PrzedpelskaWasowicz \& Wierzbicka 2011), mercurial compounds have been used to assess the contributions of aquaporins in water transport at various growth stages of plant. A reversibility of mercury effects by reducing agents like dithiothreitol (DTT) and $\beta$-mercaptoethanol (ME), have also been used in conjuction with $\mathrm{HgCl}_{2}$ in current studies that seek to evaluate the activity of aquaporins (Przedpelska-Wasowicz \& Wierzbicka 2011; Obroucheva et al. 2012; Liu et al. 2014). 
Several studies have shown that abiotic stresses such as water deficit, salinity and heavy metals differentially regulate expression of aquaporins in various plant organs (Sakurai et al. 2005; Tyerman et al. 2002; Suga et al. 2001; Alexandersson et al. 2005; Jang et al. 2004). In Arabidopsis, the expression of MIP genes in different organs in response to cold, salt, drought and ABA treatment has been determined by using a semi-quantitative slot blot analysis and quantitative real-time RT-PCR (Alexandersson et al. 2005; Weig et al. 1997). Most of the studies showed that several aquaporins were predominantly expressed in one organ and that many were markedly up or downregulated under the different stress conditions. Analysis of 33 rice MIP gene expression at different growth stages and in different plant organs also showed that gene expression varied with plant organ and growth stage (Sakurai et al. 2005). Heavy metals such as $\mathrm{Cd}, \mathrm{Cu}$ and $\mathrm{Hg}$ are known to modulate gene expression and function of MIPs in various plant species. For example, in Pisum sativum reduction of root hydraulic conductivity (Lpr) by $\mathrm{HgCl}_{2}$ treatment was accompanied by an increase in the expression of PSPIP2;1, suggesting that the increase in PSPIP2;1 might compensate for the AQPs blocked by $\mathrm{Hg}$ (Beaudette et al. 2007), whereas in Populus deltoides roots subjected to copper stress genes encoding plasmalemma (PIP) and tonoplast (TIP) AQPs were downregulated under $\mathrm{Cu}$ application (Guerra et al. 2009).

The present study was undertaken to assess the role of heavy metals $(\mathrm{Hg}, \mathrm{Zn})$, salinity $(\mathrm{NaCl})$ known aquaporin inhibitors, along with several chemical agents known to reverse the inhibitory effects of mercuric chloride in regulating the water relations via aquaporins during pea seed germination and investigated the expression and function of plasma membrane and tonoplast aquaporins in seedling tissues during seed imbibition, radicle emergence and growth.

\section{MATERIALS AND METHODS}

\section{Effect of $\mathrm{HgCl}_{2}$ on seed germination}

Seeds of pea(Pisum sativum L. cv.Arkel) were procured from Manipur Seeds Corporation, Manipur. Theyhad no visible signs of injury and were uniform in size and weight.The seeds were placed in petri dishes $(90 \mathrm{~mm}$ in diameter) lined with two layers of Whatman no.1 filter paper, moistened with $3 \mathrm{ml}$ of distilled water and $\mathrm{HgCl}_{2}$ solutions at concentrations of $100,300,500$ and $1000 \mu \mathrm{M}$. The petri dishes were incubated at $25 \pm 2^{\circ} \mathrm{C}$ in dark for 72 $\mathrm{h}$, and daily evaluations of germination were performed.
2. Effect of $\mathrm{HgCl}_{2}$, ME and DTT on activity of aquaporins

To study the involvement of aquaporins on seed germination, known aquaporin inhibitor $\mathrm{HgCl}_{2}$ and mercury scavenging agents (ME and DTT) were tested during germination as per the method of Jain et al. (2008). The seeds were placed in petridishes lined with two layers of Whatman no. 1 filter paper, moistened either with $3 \mathrm{ml}$ of the test solution i.e., $\mathrm{HgCl}_{2}(0,100,300$, or $500 \mu \mathrm{M})$ or in combination with ME $(250 \mu \mathrm{M})$ or DTT $(500 \mu \mathrm{M})$. The petri dishes were incubated at $25 \pm 2^{\circ} \mathrm{C}$ in dark for $72 \mathrm{~h}$. Five seedlings were used to calculate the percent moisture. The fresh and dry weights of seedlings were recorded, and the percentage moisture content was calculated as $\left\{\left(\mathrm{W}_{1^{-}}\right.\right.$ $\left.\left.\mathrm{W}_{2}\right) / \mathrm{W}_{1}\right\} \times 100$, where $\mathrm{W}_{1}$ and $\mathrm{W}_{2}$ represent fresh and dry weights of five seedlings, respectively. All the experiments were repeated thrice.

\section{Effect of $\mathbf{H g C l}_{2}, \mathrm{ZnCl}_{2}$ and $\mathrm{NaCl}$ on seedling growth}

In order to verify the significance of aquaporins in germinating pea seeds $\mathrm{HgCl}_{2}, \mathrm{ZnCl}_{2}$ and $\mathrm{NaCl}$ was administered in germinating pea seeds. The germinated seeds were treated with different concentrations of $\mathrm{HgCl}_{2}(100,300,500$ and $1000 \mu \mathrm{M}), \mathrm{ZnCl}_{2}(10,25,50$ and $100 \mu \mathrm{M})$ and $\mathrm{NaCl}(100,300,500$ and $1000 \mathrm{mM})$. Growth of the seedlings was determined by measuring the length of the radicle and plumule. Measurements were done inthree replicates using five plants and expressed as $\mathrm{cm}$. The data were recorded after every $24 \mathrm{~h}$ upto $72 \mathrm{~h}$.

\section{Expression study of aquaporins}

To study the effect of salt $(\mathrm{NaCl})$ and heavy metals $(\mathrm{Hg}$ and $\mathrm{Zn})$ on gene expression, germinated seeds were treated with $\mathrm{NaCl}(100 \mathrm{mM}), \mathrm{HgCl}_{2}(100$ and $300 \mu \mathrm{M})$, and $\mathrm{ZnCl}_{2}$ (50 and $100 \mu \mathrm{M})$. After $24 \mathrm{~h}$ and $48 \mathrm{~h}$, radicle, plumule and cotyledon samples were taken from each treatment for RNA extraction.100 $\mathrm{mg}$ of the tissue samples were homogenized using liquid nitrogen and the total RNA was isolated using Total RNA purification kit (Nucleopore's) following the manufacturer's instructions. The RNA isolated were quantified spectrophotometrically at 260/280 nm. Out of total RNA isolated from the seed tissues, approximately $1000 \mathrm{ng}$ was reverse transcribed using RevertAid ${ }^{\mathrm{TM}}$ First Strand cDNA Synthesis Kit \#K1622 following the manufacturer's instruction. The cDNA thus obtained was kept at $-20^{\circ} \mathrm{C}$ till further use. The gene specific primers were designed from the nucleotide sequences of PsPIP1;2 and PsTIP1;1 (Gene bank accession number: AJ548795.1 and AJ243309.1 respectively). The gene specific forward primer 5'-TGATGCAGGTTCTTGGTG-3', reverse primer 5'-CGTGCTGGGTTGATACCA-3' were used for 
amplifying PsPIPl;2, and forward primer 5'TGGCTGAGTTCATCTCCA-3', reverse primer 5'CACTCCAACTCCTGCGGA-3' were used for amplifying PsTIP1;1.The PCR conditions were in house validated and reconfirmed for each aquaporin gene. Each reaction system contained $2.5 \mu \mathrm{l}$ of $10 \mathrm{x}$ PCR buffer with $\mathrm{MgCl}_{2}, 1.0 \mu \mathrm{l}$ of 10 pmole/ $\mu 1$ each primer, $0.5 \mu 1$ Taq DNA polymerase (5 $\mathrm{U} / \mu \mathrm{l}), 2 \mu \mathrm{l}$ cDNA and the volume was made up to $25 \mu \mathrm{l}$ with deionized water.The thermal cycle used for PsPIP1;2 was as follows: $96^{\circ} \mathrm{C}$ for $2 \mathrm{~min} ; 30$ cycles of $96^{\circ} \mathrm{C}$ for $30 \mathrm{~s}$, $56^{\circ} \mathrm{C}$ for $1 \mathrm{~min}, 72^{\circ} \mathrm{C} 30 \mathrm{~s}$, and a final $72^{\circ} \mathrm{C}$ for $5 \mathrm{~min}$. The PCR reaction conditions for amplifying PsTIP1;1were the same as those for $P_{S P I P 1 ; 2}$ gene, but the annealing temperature was changed into $56^{\circ} \mathrm{C}$.The amplicons so generated were resolved on $1.2 \%$ agarose (Sigma-Aldrich,) gel electrophoresis. Then the gel was examined in Gel Doc (KODAK) and the photographs were taken.

\section{RESULTS}

\section{Effect of $\mathrm{HgCl}_{2}$ concentration on seed germination}

Initial experiments were carried out to determine the effect of various concentrations of $\mathrm{HgCl}_{2}(0,100,300,500$ and $1000 \mu \mathrm{M}$ ) on seed germination. The percentage seed germination decreased gradually up to $1000 \mu \mathrm{M}$ (Fig. 1). The seeds soaked in $100 \mu \mathrm{M} \mathrm{HgCl}_{2}$ showed similar trend in germination as the seeds soaked in water and germination percentage were not significantly different from the control. However, $1000 \mu \mathrm{M} \mathrm{HgCl}_{2}$ caused drastic reduction in germinationpercentage of the seeds.

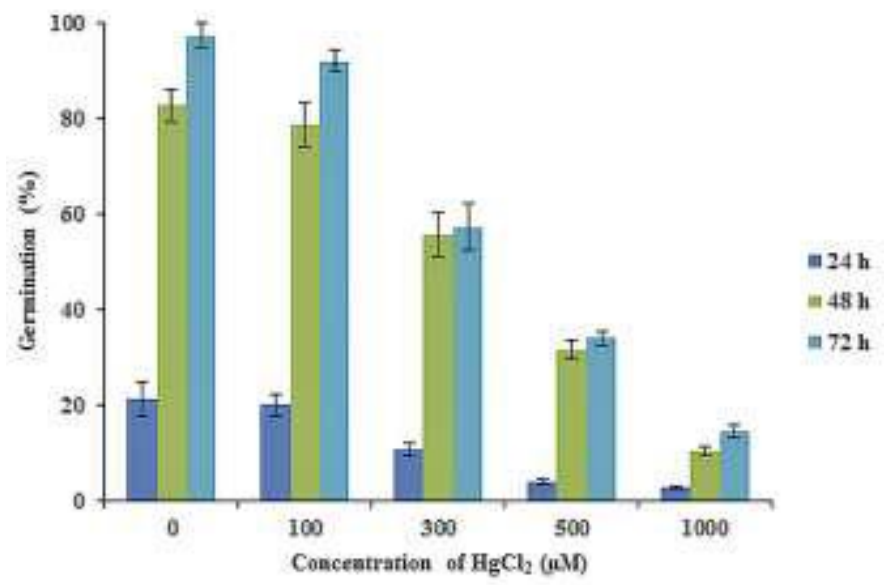

Fig. 1: Effect of different concentrations of $\mathrm{HgCl}_{2}$ upon germination percentage of pea seeds. Values are means \pm S.E. based on three independent experimental data.

2. Effect of mercury- scavenging agents on activity of aquaporins
It is well known that the inhibitory effect of $\mathrm{HgCl}_{2}$ on aquaporins can be reversed by mercury-scavenging agents such as DTT and ME. The moisture content of the seedlings wasmeasured after treatment with distilled water, $250 \mu \mathrm{M}$ $\mathrm{ME}$ and $500 \mu \mathrm{M}$ DTT. Their presence had no inhibitory effect on seedling moisture content (Fig. 2). Application of these agents individually with 100,300 or $500 \mu \mathrm{M}$ of $\mathrm{HgCl}_{2}$ overcame the inhibitory effect of $\mathrm{HgCl}_{2}$ in terms of moisture content. The seedling moisture content was significantly lower than the control with $500 \mu \mathrm{M} \quad \mathrm{ofHgCl}_{2}$. This inhibitory effect of $\mathrm{HgCl}_{2}$ was reversed by using DTT or ME (Fig. 2).

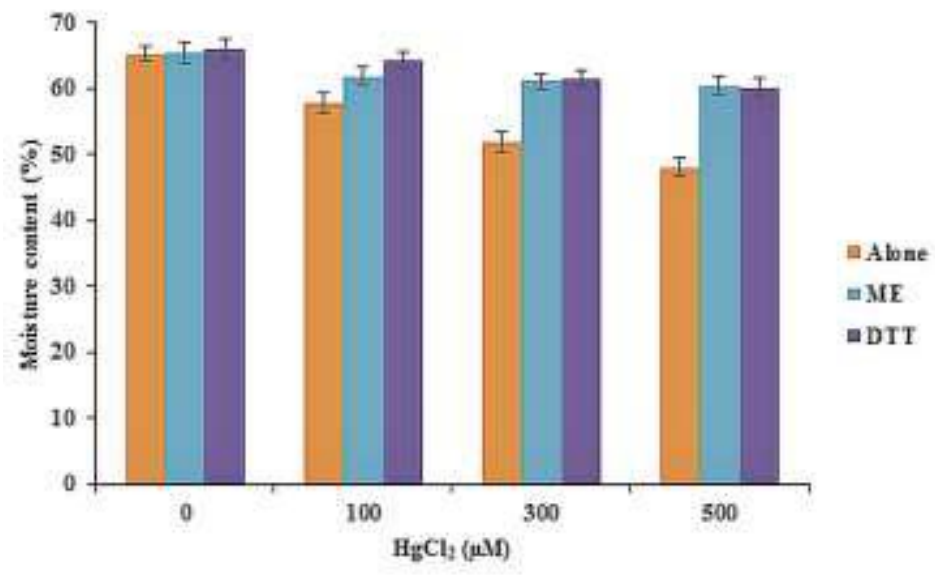

Fig. 2: Moisture content of pea seedlings germinated in the presence of different concentrations of $\mathrm{HgCl}_{2}(0,100,300$, or $500 \mu M)$ either alone or in combination with reversal agents $M E(250 \mu M)$ or DTT $(500 \mu M)$. Values are means \pm

S.E. based on three independent experimental data.

\section{Effect of $\mathrm{HgCl}_{2}, \mathrm{ZnCl}_{2}$ and $\mathrm{NaCl}$ on seedling growth}

Radicle and plumule length were measured to illustrate the impact of $\mathrm{HgCl}_{2}, \mathrm{ZnCl}_{2}$ and $\mathrm{NaCl}$ upon the growth of pea seedlings. Different concentrations of $\mathrm{HgCl}_{2}(100,300,500$ and $1000 \mu \mathrm{M}$ ) showed marked impact upon the measured growth parameters in pea seedlings. Both radicle and plumule length significantly inhibited at high concentration $(1000 \mu \mathrm{M})$ as compared with the control (Fig. 3). Seed germination in $\mathrm{ZnCl}_{2}$ also had reduced radicle and plumule length at a concentration of $100 \mu \mathrm{M}$ compared to the control (Fig. 4). In the present study, radicle and plumule length decreased progressively with increasing $\mathrm{NaCl}$ concentration (Fig. 5). 

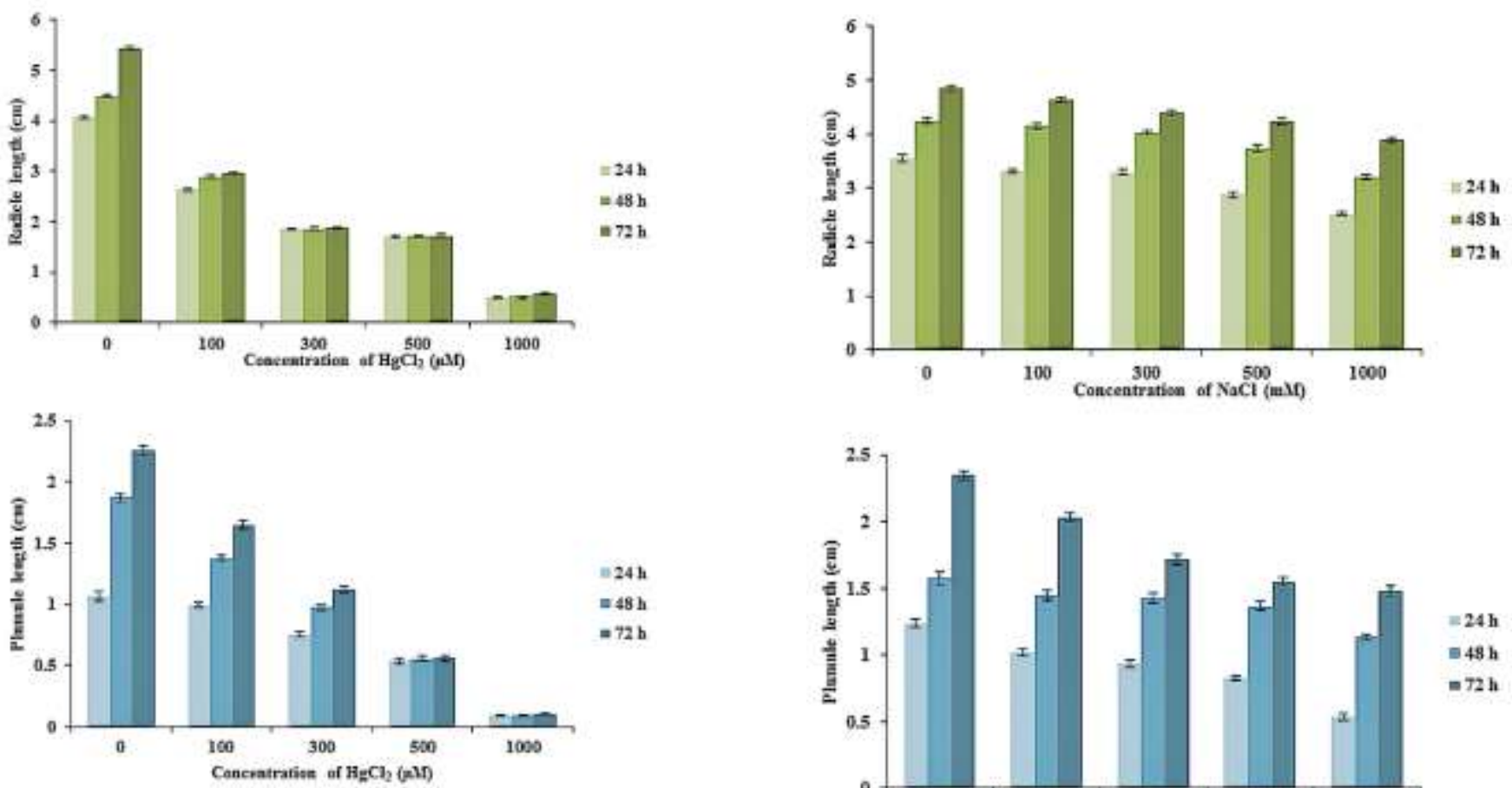

Fig. 3: Effect of different concentrations of $\mathrm{HgCl}_{2}$ upon radicle length, plumule length of pea seedlings. Values are means \pm S.E. based on three independent experimental data.
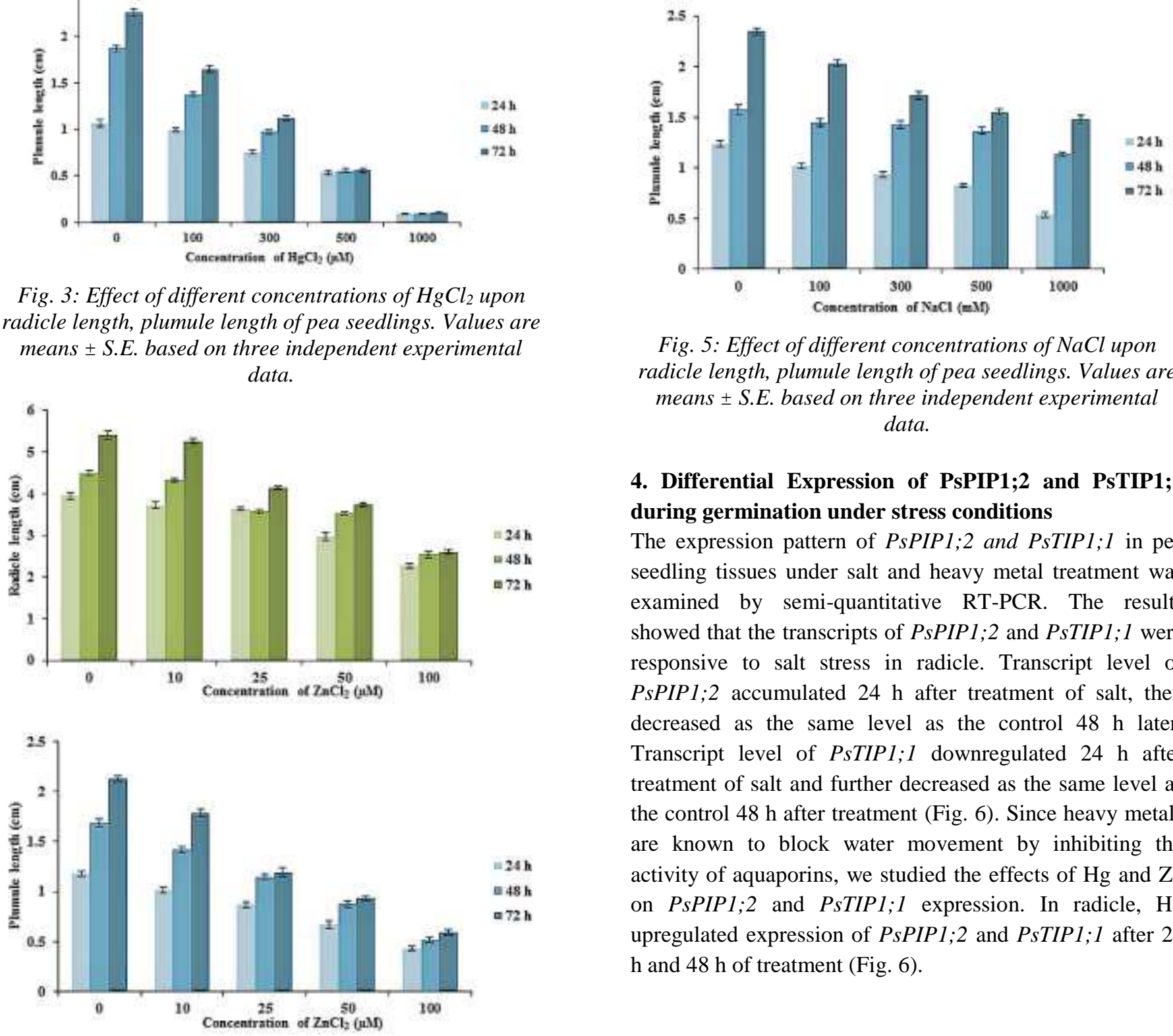

Fig. 5: Effect of different concentrations of $\mathrm{NaCl}$ upon radicle length, plumule length of pea seedlings. Values are means \pm S.E. based on three independent experimental data.

\section{Differential Expression of PsPIP1;2 and PsTIP1;1 during germination under stress conditions}

The expression pattern of PSPIP1;2 and PsTIP1;1 in pea seedling tissues under salt and heavy metal treatment was examined by semi-quantitative RT-PCR. The results showed that the transcripts of PSPIP1;2 and PSTIP1;1 were responsive to salt stress in radicle. Transcript level of PSPIP 1;2 accumulated $24 \mathrm{~h}$ after treatment of salt, then decreased as the same level as the control $48 \mathrm{~h}$ later. Transcript level of PsTIP1;1 downregulated $24 \mathrm{~h}$ after treatment of salt and further decreased as the same level as the control $48 \mathrm{~h}$ after treatment (Fig. 6). Since heavy metals are known to block water movement by inhibiting the activity of aquaporins, we studied the effects of $\mathrm{Hg}$ and $\mathrm{Zn}$ on PSPIP1;2 and PsTIP1;1 expression. In radicle, $\mathrm{Hg}$ upregulated expression of PSPIP1;2 and PSTIP1;1 after 24 $\mathrm{h}$ and $48 \mathrm{~h}$ of treatment (Fig. 6).

Fig. 4: Effect of different concentrations of $\mathrm{ZnCl}_{2}$ upon radicle length, plumule length of pea seedlings. Values are means \pm S.E. based on three independent experimental data. 

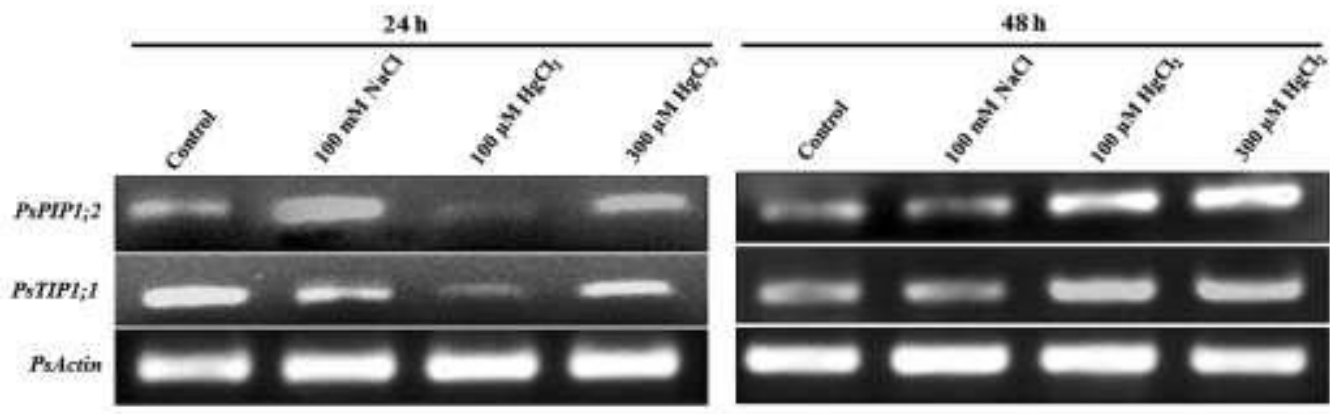

Fig. 6: Tissue Expression pattern of PsPIP1;2 and PsTIP1;1 in radicle of pea seedlings after $24 \mathrm{~h}$ and $48 \mathrm{~h}$ of treatment with 100 $m \mathrm{M} \mathrm{NaCl}, 100 \mu \mathrm{M} \mathrm{HgCl}$ and $300 \mu \mathrm{M} \mathrm{HgCl}$; PsActin primers were used as internal control.

Expression of PsTIP1;1 was studied under different concentrations of Zn stress after $24 \mathrm{~h}$ in cotyledon, plumule and radicle.Zn downregulated expression of PSTIP1; 1 in cotyledon whereas upregulated in radicle. Expression of PsTIP1;1 was not affected in plumule (Fig. 7).

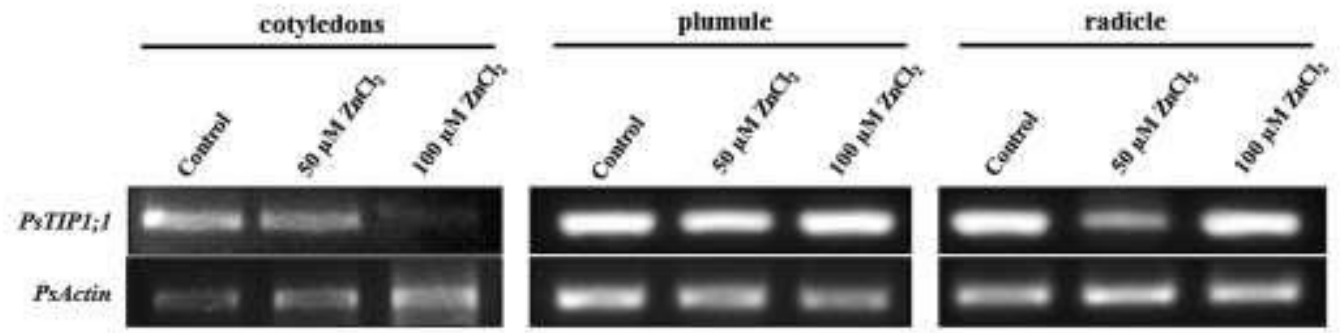

Fig.7: Tissue Expression pattern of PsTIP1;1 under ZnCl2 stress in pea seedlings. PsTIP1;1 expression in cotyledons, plumule and radicle after $24 \mathrm{~h}$ treatment with 50 and $100 \mu \mathrm{M} \mathrm{ZnCl} 2 ; P$ sActin primers were used as internal control.

\section{DISCUSSION}

Mercury at different concentrations affect seed germination differently.Higher concentrations of mercury cause death of the seed embryo by exerting oxidative stress and damaging cellular components. Mercury at low concentrations affectsseed germination by changing the hydration pattern (Munzuroglu \& Geckil 2002; Jain et al. 2008).In previous studies mercurials reduced the speed of seed imbibition and seed germination in pea and Arabidopsis, respectively (Veselova et al. 2003; Vander Willigen et al. 2006). Since mercury blocks aquaporin activity and aquaporins play major role in transmembrane transport of water (Aroca et al. 2012), high concentration of $\mathrm{HgCl}_{2}$ might have suppressed aquaporin activity and subsequent reduction in hydration and germination.

In this study, addition of DTT and ME to $\mathrm{HgCl}_{2}$ treated seeds reduced the inhibition of imbibition. Similar results were obtained by Jain et al. (2008) in which addition of DTT and ME overcame the inhibitory effect of $\mathrm{HgCl}_{2}$ on tomato seed germination and moisture content. Veselova and Veselovsky (2006) reported that DTT restored reduced rate of water uptake by mercury-containing compound in pea.

Excessive accumulation of heavy metals in the soil environment due to rapid industrialization, urbanization and intensive agriculture adversely affects the germination of seeds, plant growth, alters the level of biomolecules in the cells and interferes with the activities of many key enzymes related to normal metabolic and developmental processes (Parmar \& Chanda 2005; Jayakumaret al. 2008; Ogundiran2007). Diminution in plant growth is one of the clearest symptoms induced by heavy metals.Reduced root and shoot length in response to heavy metal has been reported by a number of investigators (Nag et al. 1989; Zhenguo et al. 1998; Tomulescuet al. 2004; Zhanget al. 2009; John etal. 2009).The visible symptoms of mercuric chloride toxicity were decrease in germination percentage, decrease in radicle length and plumule length. Root growth inhibition and lateral roots development are symptoms of mercury toxicity which can be attributed to the inhibition of mitosis, reduced synthesis of cell wall components and changes in photosynthetic activity. Similar observations with $\mathrm{HgCl}_{2}$ treatment to Arachis hyposea seeds were 
noticed by Abraham and Damodaran (2012).To further substantiate the results, $\mathrm{ZnCl}_{2}$, another inhibitor of aquaporins, was used. $\mathrm{ZnCl}_{2}$ inhibits water transport in a permanent manner as it reacts with sulfhydryl groups of a cysteine in the vicinity of the conserved NPA motif, blocking the constriction region of the channel (Niemietz \& Tyerman, 2002). According to Flowers et al.(2010) salinity (as $\mathrm{NaCl}$ ) reduces seed germination and growth of pea seedlings. There is reduction in both seedling growth and root growth. It may be due to the fact that the root cannot balance the nutrient uptake due to osmosis. The osmotic effect takes place during salt stress which affects seed germination (Welbaum et al. 1990) which in turn slows down the water uptake by the plant. Neuman (1995) also observed that salinity inhibits root growth rapidly and hence the capacity of water uptake. Similar results were observed by Demir and Arif (2003) in safflower. This osmotic effect in the plant cell cause negative pressure in the pore of water channel affecting hydraulic conductivity (Ye et al. 2004). The hydraulic conductivity when lower also lowers the aquaporins activity. The reduction in root hydraulic conductivity is also correlated with a dynamic change in the post-translational modifications such as phosphorylation and amidation that affect aquaporin function(Khan et al. 2015). Aquaporin is also altered by ROS which leads to channel closure through a direct oxidative mechanism (Kourie 1998), and induces internalization of PIPs and reduces hydraulic conductivity through cell signaling mechanisms (Boursiac et al. 2008a, Boursiac et al. 2008b).

Since abiotic stresses such as salt and heavy metals induce osmotic stress to plants and disturb plant water balance, we tried to investigate the molecular mechanisms involved in maintaining osmotic homeostasis by studying gene expression and water transport activity of one PIP and one TIP isoforms in pea. Transcripts of PSPIP1;2 and PsTIP1;1 studied were detected in both radicle and plumule at different levels. Our results showed that transcript levels responded differently to $100 \mathrm{mM} \mathrm{NaCl}$ treatment depending on the type of gene. In radicle, salt stress significantly upregulated transcript of PSPIP1;2during the initial $24 \mathrm{~h}$ of treatment but reached to same level as of unstressed after 48 $\mathrm{h}$ of treatment. The transient induction of PSPIP1;2 by salt stress might confer the membrane permeability to water transport in water-deficient condition (Yamada et al. 1997). Our study is in accordance with a real-time PCR analysis of PIP gene expression (Jang et al. 2004), which revealed in salt-treated roots an increase in abundance more pronounced for PIP genes. Salt stress downregulated the expression of PSTIP1; lafter 24 and $48 \mathrm{~h}$ of treatment. At the gene level, expression of TIPs and PIPs was co-ordinately reduced. This could mean that TIPs also contribute to control transcellular water transport in radicle. Mercury, having inhibitory effect on water transport activity (Carvajal et al. 1996; Maggio \& Joly 1995) stimulated gene expression as in the current study and as reported earlier in pea(Beaudette et al. 2007). Mercury enhancing transcript accumulation of PSPIP1;2 and PSTIP1;1, suggests that seedlings tend to overcome water shortage by compensating the water channels blocked by $\mathrm{Hg}$.

Being the aquaporins of the tonoplast, TIPs are thought to permit a more rapid transcellular water flow by increasing the effective cross-section of the cytoplasm, and to facilitate osmotic adjustment between cytosol and vacuole (Barrieu et al. 1998). Previously Schuurmans et al. (2003) found PSTIP1; 1 and/or its close homologues and their abundant expression in cotyledons of developing and germinating pea seeds, and in roots and shoots of seedlingsand concluded that TIP1 members play a role in the rehydration of the dry seed during imbibition and subsequent germination. In our case, expression of PSTIPI;1 was significantly high in plumule and radicle which wasconsistent with the expression pattern of TIP1s in Arabidopsis (Alexandersson et al. 2005). The expression of PsTIP1;1 upregulated by $\mathrm{Zn}$ in radicle and suppressed in cotyledon after $24 \mathrm{~h}$ of treatment and was not affected in plumule. High expression of PSTIP1;1 might contribute to transcellular water transport in germinating seeds and facilitate water supply to expanding tissues.

\section{CONCLUSION}

Based on the results of our study, higher concentration of mercuric chloride suppressed aquaporin activity and subsequent reduction in hydration and germination of pea seeds.Addition of mercury scavenging agents along with $\mathrm{HgCl}_{2}$ overcame the inhibitory effects. It concludes a putative role for aquaporins in controlling pea seed germination, by possibly acting in the initial phases of germination. The presence of aquaporin inhibitors $\left(\mathrm{HgCl}_{2}\right.$ and $\mathrm{ZnCl}_{2}$ ) and $\mathrm{NaCl}$ reduced seedling growth and differentially regulated expression of plasma membrane intrinsic protein $(P S P I P 1 ; 2)$ and tonoplast intrinsic protein $(P s T I P 1 ; 1)$ in different parts of the seedlings, suggesting that the isoforms have a distinct role under these stress conditions.

\section{ACKNOWLEDGEMENTS}

We acknowledge Manipur Seeds Corporation, Manipur, India for providing pea seeds. 


\section{REFERENCES}

[1] Abraham K, Damodharan T. 2012. Effect of mercury on germination and seedling growth of Arachis hypogeae L. Annals of Biological Research 3:32973299.

[2] Agre P, Bonhivers M, Borgnia MJ. 1998. The aquaporins, blueprints for cellular plumbing systems. Journal of Biological Chemistry 273:14659-62.

[3] Alexandersson E, Fraysse L, Sjövall-Larsen S, Gustavsson S, Fellert M, Karlsson M et al. 2005. Whole gene family expression and drought stress regulation of aquaporins. Plant Molecular Biology 59:469-484.

[4] Almansouri M, Kinet JM, Lutts S. 2001. Effect of salt and osmotic stresses on germination in durum wheat (Triticum durum Desf.). Plant and Soil 231:243-254.

[5] Aroca R, Porcel R, Ruiz-Lozano JM. 2012. Regulation of root water uptake under abiotic stress conditions. Journal of Experimental Botany 63:43-57.

[6] Barrieu F, Chaumont F, Chrispeels MJ. 1998. High expression of the tonoplast aquaporin ZmTIP1 in epidermal and conducting tissues of maize. Plant Physiol 117: 1153-1163.

[7] Beaudette PC, Chlup M, Yee J, Emery RN. 2007. Relationships of root conductivity and aquaporin gene expression in Pisum sativum: diurnal patterns and the response to $\mathrm{HgCl}_{2}$ and ABA. Journal of Experimental Botany 58:1291-300.

[8] Bhattacharjee S. 2008. Triadimefon pretreatment protects newly assembled membrane system and causes up-regulation of stress proteins in salinity stressed Amaranthus lividus L. during early germination. J Environ Biol 29:805-810.

[9] Boursiac Y, Boudet J, Postaire O, Luu DT, TournaireRoux C, Maurel C. 2008a. Stimulus-induced downregulation of root water transport involves reactive oxygen species-activated cell signaling and plasma membrane intrinsic protein internalization. Plant J 56:207-218.

[10]Boursiac Y, Prak S, Boudet J, Postaire O, Luu, DT, Tournaire-Roux C. 2008b. The response of Arabidopsis root water transport to a challenging environment implicates reactive oxygen species- and phosphorylation-dependent internalization of aquaporins. Plant Signal Behav 3:1096-1098.

[11]Cardoso AÁ, Souza GA, Silva CJ, Pires RM, Dias DC. 2015. Seed imbibition and germination of Plathymenia reticulata Benth.(Fabaceae) affected by mercury: possible role of aquaporins. Acta Botanica Brasilica 29:285-291.

[12] Carvajal M, Cooke DT, Clarkson DT. 1996. Plasma membrane fluidity and hydraulic conductance in wheat roots: interactions between root temperature and nitrate or phosphate deprivation. Plant, Cell \& Environment 19(9):1110-4.

[13] Chugh LK, Sawhney SK. 1996. Effect of cadmium on germination, amylases and rate of respiration of germinating pea seeds. Environmental Pollution 92:1-5.

[14]Daniels MJ, Mirkov TE, Chrispeels MJ. 1994. The plasma-membrane of Arabidopsis thaliana contains a mercury-insensitive aquaporin that is a homologue of the tonoplast water channel proteinTIP. Plant Physiol 106:1325-1333.

[15] Demir M, Arif I. 2003. Effects of different soil salinity levels on germination and seedling growth of safflower (Carthamus tinctorius L.). Turkish Journal of Agriculture 27: 221-227.

[16] Dow MA, Schwintzer CR. 1999. Seed germination, seedling emergence, and seed bank ecology of sweet fern (Comptonia peregrine (L.) Coult.). Canadian Journal of Botany 77:1378-1386.

[17] Du LF, Shen ZG, Yu D, Liu WH, Deng Y, Zhou YF. 2004. Toxological effect of mercury stress on pea seed. Acta Botanica Boreali-occidentalia Sinica 24:2266.

[18]Flowers TJ, Gaur PM, Gowda CLL. 2010. Salt sensitivity in chickpea. Plant Cell and Environment 33: 490-50.

[19] Guerra F, Duplessis S, Kohler A, Martin F, Tapia J, Lebed $\mathrm{P}$ et al. 2009. Gene expression analysis of Populus deltoides roots subjected to copper stress. Environmental and Experimental Botany 67:335-344.

[20] Jain N, Ascough GD, Van Staden J. 2008. A smokederived butenolide alleviates $\mathrm{HgCl}_{2}$ and $\mathrm{ZnCl}_{2}$ inhibition of water uptake during germination and subsequent growth of tomato-Possible involvement of aquaporins. Journal of plant physiology 165:1422-7.

[21] Jang JY, Kim DG, Kim YO, Kim JS, Kang H. 2004. An expression analysis of a gene family encoding plasma membrane aquaporins in response to abiotic stresses in Arabidopsis thaliana. Plant Molecular Biology 54:713-725.

[22] Jayakumar K, Jaleel CA, Azooz MM. 2008. Impact of cobalt on germination and seedling growth of Eleusine coracanaL. and Oryza sativa L. under hydroponic culture. Global Journal of Molecular Sciences 3(1):1820. 
[23] John R, Ahmad P, Gadgil K, Sharma S. 2009. Heavy metal toxicity: Effect on plant growth, biochemical parameters and metal accumulation by Brassica juncea L. Int J Plant Prod 3: 65-76.

[24] Khan K, Agarwal P, Shanware A, Sane VA. 2015. Heterologous expression of two Jatropha aquaporins imparts drought and salt tolerance and improves seed viability in transgenic Arabidopsis thaliana. PloS one 10:e0128866.

[25] Kourie JI. 1998. Interaction of reactive oxygen species with ion transport mechanisms. Amer J Physiol.275: C1-C24.

[26] Liu C, Fukumoto T, Matsumoto T, Gena P, Frascaria D, Kaneko $\mathrm{T}$ et al. 2013. Aquaporin OsPIP1;1 promotes rice salt resistance and seed germination. Plant Physiology and Biochemistry 63:151-158.

[27] Liu HY, Yu X, Cui DY, Sun MH, Sun WN, Tang ZC et al. 2007. The role of water channel proteins and nitric oxide signaling in rice seed germination. Cell research 17:638-649.

[28]Liu P, Yin L, Deng X, Wang S, Tanaka K, Zhang S. 2014. Aquaporin-mediated increase in root hydraulic conductance is involved in silicon-induced improved root water uptake under osmotic stress in Sorghum bicolor L. Journal of Experimental Botany 65:47474756.

[29] Maggio A, Joly RJ. 1995. Effects of mercuric chloride on the hydraulic conductivity of tomato root systems (evidence for a channel-mediated water pathway). Plant Physiology 109(1):331-5.

[30] Maurel C, Boursiac Y, Luu DT, Santoni V, Shahzad Z, Verdoucq L. 2015. Aquaporins in plants. Physiological Reviews 95(4):1321-1358.

[31] Munzuroglu O, Geekil H. 2002. Effect of metals on seed germination, root elongation and coeoptiles and hypocotyls growth in Triticum aestivum and Cucumis salivus. Arch Environ Contam Toxicol. 43:203-213.

[32] Nag P, Paul AK, Mukherji S. 1989. The effects of heavy metals, $\mathrm{Zn}$ and $\mathrm{Hg}$, on the growth and biochemical constituents of mungbean (Vigna radiata) seedlings. Bot Bull Academia Sinica 30:241-250.

[33] Nonogaki H, Bassel GW, Bewley JD. 2010. Germination - Still a mystery. Plant Science 179: 574581.

[34] Neumann PM. 1995. Inhibition of root growth by salinity stress: Toxicity or an adaptive biophysical response. In: Baluska F, Ciamporova M, Gasparikova, $\mathrm{O}$, Barlow PW, editors, Structure and Function of
Roots. The Netherlands: Kluwer Academic Publishers. pp. 299-304.

[35] Niemietz CM, Tyerman SD. 2002. New potent inhibitors of aquaporins: silver and gold compounds inhibit aquaporins of plant and human origin. FEBS Letters 531:443-7.

[36] Obroucheva NV, Lityagina SV, Novikova GV, Sin'kevich IA. 2012. Vacuolar status and water relations in embryonic axes of recalcitrant Aesculus hippocastanum seeds during stratification and early germination. AoB Plants 2012:pls008.

[37] Ogundiran MB. 2007. Assessment and chemical remediation of soil contaminated by lead-acid batterywaste in Lalupon, Oyo State, Nigeria. PhD dissertation, University of Ibadan, Ibadan, Nigeria.

[38] Parmar G, Chanda V. 2005. Effects of Mercury and Chromium on Peroxidase and IAA Oxidase Enzymes in the Seedlings of Phaseolus vulgaris. Turk J Biol 29: 15-21.

[39] Preston GM, Carroll TP, Guggino WB, Agre P. 1992. Appearance of water channels in Xenopus oocytes expressing red cell CHIP28 protein.Science 256: $385-$ 387.

[40] Przedpelska-Wasowicz EM, Wierzbicka M. 2011. Gating of aquaporins by heavy metals in Allium cepa L. epidermal cells. Protoplasma 248:663-671.

[41] Rout GR, Das P. 2009. Effect of metal toxicity on plant growth and metabolism: I. Zinc. In: Sustainable Agriculture. Springer Netherlands pp 873-884.

[42] Sakurai J, Ishikawa F, Yamaguchi T, Uemura M, Maeshima M. 2005. Identification of 33 rice aquaporin genes and analysis of their expression and function. Plant and Cell Physiology 46:1568-1577.

[43] Schuurmans JA, van Dongen JT, Rutjens BP, Boonman A, Pieterse CM, Borstlap AC. 2003. Members of the aquaporin family in the developing pea seed coat include representatives of the PIP, TIP, and NIP subfamilies. Plant Molecular Biology53:655-667.

[44] Suga S, Imagawa S, Maeshima M. 2001. Specificity of the accumulation of mRNAs and proteins of the plasma membrane and tonoplast aquaporins in radish organs. Planta 212:294-304.

[45] Tomulescu IM, Radoviciu EM, Merca VV, Tuduce AD. 2004. Effect of copper, zinc and lead and their combinations on the germination capacity of two cereals. Journal of Agricultural Sciences 15:39-42.

[46] Tyerman SD, Niemietz CM, Bramley H. 2002. Plant aquaporins: multifunctional water and solute channels 
with expanding roles. Plant, Cell \& Environment 25:173-194.

[47] Vander Willigen C, Postaire O, Tournaire-Roux C, Boursiac Y, Maurel C. 2006. Expression and inhibition of aquaporins in germinating Arabidopsis seeds. Plant Cell Physiol47:1241-50.

[48] Veselova TV, Veselovsky VA. 2006. Possible involvement of aquaporins in water uptake by pea seeds differing in quality. Russian Journal of Plant Physiology 53: 96-101.

[49] Veselova TV, Veselovskii VA, Usmanov PD, Usmanova OV, Kozar VI. 2003. Hypoxia and imbibition injuries to aging seeds. Russian Journal of Plant Physiology50:835-42.

[50] Weig A, Deswarte C, Chrispeels MJ. 1997. The major intrinsic protein family of Arabidopsis has 23 members that form three distinct groups with functional aquaporins in each group. Plant Physiology 114:13471357.

[51] Welbaum GE, Tissaoui T, Bradford KJ. 1990. Water relations of seed development and germination in muskmelon (Cucumis melo L.). III. Sensitivity of germination to water potential and abscisic acid during development. Plant Physiol 92:1029-1037.

[52] Yamada S, Komori T, Myers PN, Kuwata S, Kubo T, Imaseki H. 1997. Expression of plasma membrane water channel genes under water stress in Nicotiana excelsior. Plant Cell Physiol 38(11): 1226-1231.

[53] Ye Q, Wiera B, Steudle E.2004. A cohesion/tension mechanism explains the gating of water channels (aquaporins) in Chara internodes by high concentration. J ExpBot 55: 449-461.

[54]Zhang H, Lian C, Shen Z. 2009. Proteomic identificationof small, copper-responsive proteins in germinating embryos of Oryza sativa. Ann Bot 103:923-930.

[55]Zhenguo S, Zhang F, Zhang F. 1998. Toxicity of copper and zinc in seedlings of mung bean and inducing accumulation of polyamine. J Plant Nutrition 21:1153-1162. 